A Guide to

The Preparation of Civil Engineering Drawings 
All royalties from the sale of this book will be donated to Oxfam in support of the United Nations' campaign to bring safe water and sanitation to everyone in poor countries by 1990 .

Ninety per cent of children's deaths in poor countries could have been avoided by safe water and sanitation.

Water for irrigating crops can mean three harvests instead of one. So families would not go hungry in the dry season.

The World Health Organization estimates that eighty per cent of all disease in the world is linked with water.

People cannot stay healthy when they are dependent on inadequate water infected by parasites, polluted by sewage or fouled by animals. 


\section{A Guide to \\ THE PREPARATION OF CIVIL ENGINEERING DRAWINGS}

\section{V. THOMAS}

C.Eng., M.I.Mun. E. 
Softcover reprint of the hardcover 1st edition 1982 978-0-333-28081-2

All rights reserved. No part of this publication may be reproduced or transmitted, in any form or by any means, without permission.

First published 1982 by THE MACMILLAN PRESS LTD

London and Basingstoke Companies and representatives throughout the world

Typeset in Great Britain by PINTAIL STUDIOS LTD Ringwood, Hampshire

\section{To Glenys \\ Catherine \\ Lynette \\ and Clare}

The paperback edition of the book is sold subject to the conditon that it shall not, by way of trade or otherwise be lent, resold, hired out, or otherwise circulated without the publisher's prior consent in any form of binding or cover other than that in which it is published and without a similar condition iricluding this condition being imposed on the subsequent purchaser. 


\section{CONTENTS}

\section{Introduction}

1. General Principles

1.1 Introduction

1.2 Drawing Instruments

1.3 Drawing Office Practice

1.4 Health and Environment

1.5 Layout

1.6 Draughting, Tracing and Colouring

2. Drawing Office Layout, Control and Reproduction

2.1 Introduction

2.2 Office Layout

2.3 Drawing Control and Filing

2.4 Drawing Reproduction

3. Projections and Basic Geometry

3.1 Introduction

3.2 Orthographic Projection

3.3 Auxiliary Projection

3.4 True Lengths

3.5 Plans, Elevations and Sections

3.6 Basic Geometry

4. Three-dimensional Drawing and Sketching

4.1 Introduction

4.2 Sketching

4.3 Constructed Three-dimensional Drawings

\section{Graphic and Pictorial Methods of}

Design and Presentation 73

5.1 Introduction $\quad 73$

5.2 Charts, Graphs and Diagrams $\quad 73$

5.3 Models $\quad 82$

6. Computer Graphics 86

6.1 Introduction $\quad 86$

7. Drawing Applications 97

$\begin{array}{ll}7.1 \text { Introduction } & 97\end{array}$

$\begin{array}{ll}7.2 \text { Surveying } & 98\end{array}$

7.3 Site Investigations $\quad 106$

$\begin{array}{ll}7.4 \text { Detailing } & 107\end{array}$

7.5 The Design and Construction of a
Small Pedestrian Subway

$\begin{array}{ll}7.6 \text { Records } & 156\end{array}$

$\begin{array}{ll}7.7 \text { Conclusion } & 163\end{array}$

Appendix I Examples of Constructed Perspective $\quad 164$

Appendix II The Use of Calculators in the Design Office 172

Appendix III Public Utilities $\quad 175$

$\begin{array}{ll}\text { Index } & 178\end{array}$ 


\section{ACKNOWLEDGEMENTS}

The author particularly wishes to acknowledge the assistance of S.W. Farmer \& Son Ltd, Tektronix (U.K.) Ltd, Building Computer Services Ltd, Computer Aided Design Centre, the London Borough of Ealing, Ove Arup Partnership and Thamesdown Borough Council.

$\mathrm{He}$ is also grateful for information supplied by the Public Utility organisations, the Department of Transport, Robert Watson \& Co., the British Standards Institution, Benson Electronics Ltd, British Constructional Steelwork Association Ltd, Building Design Partnership (Preston), Loughborough University of Technology, Cement and Concrete Association, Hartley Reece \& Company, British Thornton Ltd, Elite Manufacturing Co. Ltd, Dow-Mac Concrete Ltd, Sanders \& Forster Ltd, Wild Heerbrugg (U.K.) Ltd, Spectra Alignment Ltd, Acrow (Engineers) Ltd, the National Reprographic Centre for documentation, Caps Microfilm Ltd, Cartographical Services Ltd, Addressograph-Multigraph Ltd, Gaf (G.B.) Ltd, Regma Ltd and Lamwood Ltd.

The author would also like to thank A.E. Hurren of Portsmouth Polytechnic for his helpful and constructive comments on the manuscript.

This project could not have been undertaken without the helpful cooperation of the publisher and the help, encouragement and best wishes of family and friends. 